\title{
PENYULUHAN MENGATASI KEUANGAN KELUARGA PADA MASA PANDEMI COVID-19
}

\author{
Siti Fatimah Sihotang \\ Universitas Potensi Utama \\ e-mail: siti.fatimah.sihotang@gmail.com
}

\begin{abstract}
The Covid-19 pandemic had a significant impact on the economy of the Indonesian people. Many people have complained and their activities have stopped due to the Covid-19 pandemic. The economic uncertainty caused by the Covid-19 pandemic in recent months has also resulted in a decrease / loss of household income. Even the Covid-19 Pandemic had also confused many people whose profession is as traders because there is no income in their daily lives due to the limitation of people's movements. As a result, many people found it difficult to find money to fulfill their daily lives. Of course this is a new problem, where this problem directly affected the family's financial economy in the midst of community life. In a situation like this, it is the housewives who had the most role in managing the finances of their respective families. Thus, this study aimed to help housewives managed family finances during the Covid-19 pandemic and help housewives to be able to better managed family finances during the Covid-19 pandemic. Therefore, steps are needed. The right and careful steps so that the family's financial management becomes right on target. One of the efforts that can be done is to carry out Family Financial Management. After the implementation of this community service activity in the form of counseling, the knowledge and understanding of the women administrators and heads of the Medan HWK (Himpunan Wanita Karya) organization increased. This is indicated by the fact that after the researcher had explained the concept of family financial management accompanied by examples of financial calculations in the family, the participants are able to understand well, at which time the participants are able to make cash flow of their respective families' finances and are able to manage it properly. The training participants had been able to manage and manage family finances during the Covid-19 pandemic according to the theory taught by the researchers.
\end{abstract}

Keywords: Covid-19, Income, Family Finances, Economy 


\section{ABSTRAK}

Pandemi Covid-19 memberikan dampak yang signifikan terhadap perekonomian masyarakat Indonesia. Banyak masyarakat yang mengeluh dan terhenti aktivitasnya karena pandemi Covid-19. Ketidakpastian ekonomi yang disebabkan oleh pandemi Covid-19 beberapa bulan ini ternyata juga ikut mengakibatkan turun/ hilangnya pendapatan rumah tangga. Bahkan Pandemi Covid-19 juga membuat banyak masyarakat yang profesinya rata-rata sebagai pedagang kebingungan karena tidak ada pemasukan dalam kehidupannya sehari-hari akibat dibatasinya pergerakan masyarakat. Akibatnya, banyak masyarakat yang kesulitan mencari uang untuk memenuhi kehidupannya sehari-hari. Tentu hal ini menjadi suatu permasalahan yang baru, yang mana persoalan ini secara langsung berpengaruh terhadap ekonomi keuangan keluarga di tengah-tengah kehidupan masyarakat. Dalam situasi seperti ini, para ibu rumah tangga lah yang paling berperan dalam mengatur keuangan keluarga nya masing-masing. Dengan demikian, penelitian ini bertujuan untuk membantu para ibu rumah tangga untuk dapat mengatur keuangan keluarga pada masa pandemi Covid-19 dan membantu para ibu rumah tangga untuk bisa mengelola keuangan keluarga yang lebih baik pada masa pandemi Covid - 19. Oleh karena itu, diperlukan langkah - langkah yang tepat dan cermat agar pengelolaan keuangan kelurga menjadi tepat sasaran. Salah satu upaya yang dapat dilakukan adalah dengan melakukan Manajamen Keuangan Keluarga. Setelah dilaksanakannya kegiatan pengabdian pada masyarakat dalam bentuk penyuluhan ini, pengetahuan dan pemahaman Ibu - Ibu pengurus dan Ketua organisasi HWK (Himpunan Wanita Karya) Medan meningkat. Hal ini ditandai dengan setelah peneliti menjelaskan konsep manajemen keuangan keluarga yang disertai dengan contoh-contoh perhitungan keuangan dalam keluarga, para peserta mampu memahami dengan baik, yang mana pada saat itu para peserta mampu membuat cash flow keuangan keluarga masing-masing dan mampu memanage nya dengan baik. Para peserta pelatihan telah mampu dalam hal mengatur dan mengelola keuangan keluarga pada masa pandemi Covid - 19 dengan baik sesuai teori yang diajarkan oleh peneliti.

Kata Kunci : Covid-19, Pendapatan, Ekonomi, Manajemen Keuangan Keluarga 


\section{A. PENDAHULUAN}

Corona virus adalah kumpulan virus yang bisa menginfeksi sistem pernapasan. Pada banyak kasus, virus ini hanya menyebabkan infeksi pernapasan ringan, seperti flu. Namun, virus ini juga bisa menyebabkan infeksi pernapasan berat, seperti infeksi paru-paru (pneumonia). Virus ini menular melalui percikan dahak (droplet) dari saluran pernapasan, misalnya ketika berada di ruang tertutup yang ramai dengan sirkulasi udara yang kurang baik atau kontak langsung dengan droplet. Infeksi virus Corona disebut Covid-19 (Corona Virus Disease 2019) dan pertama kali ditemukan di kota Wuhan, China pada akhir Desember 2019. Virus ini menular dengan sangat cepat dan telah menyebar ke hampir semua negara, termasuk Indonesia, hanya dalam waktu beberapa bulan (He dkk., 2020). Sampai saat ini terdapat 188 negara yang mengkorfirmasi terkena virus Corona. Penyebaran virus Corona yang telah meluas ke berbagai belahan dunia membawa dampak pada perekonomian Indonesia, baik dari sisi ekonomi, perdagangan, investasi dan pariwisata. Bank Indonesia berusaha mempertahankan perekonomian Indonesia di tengah perekonomian global yang sedang terguncang. Penyebaran Covid-19 yang begitu cepat dan masif telah menggerus sendi-sendi perekonomian nasional. Adanya masalah Covid-19 mengakibatkan perekonomian indonesia menurun sampai $5 \%$ atau akan mendekati yang lebih rendah dan juga indeks harga saham megalami pelemahan yang signifikan, bahkan beberapa perusahaan BUMN ikut merugi pada tahun ini (Hanoatubun, 2020).

Tidak dapat dibantah lagi jika pandemi Covid-19 memberikan dampak yang signifikan terhadap perekonomian masyarakat Indonesia. Banyak masyarakat yang mengeluh dan terhenti aktivitasnya karena pandemi Covid-19. Bidang ekonomi menjadi sangat penting untuk 
dibahas karena ekonomi adalah salah satu faktor penting dalam kehidupan manusia. Dapat dipastikan dalam keseharian kehidupan manusia selalu bersinggungan dengan kebutuhan ekonomi. Keberadaan ekonomi dapat memberikan kesempatan bagi manusia untuk memenuhi kebutuhan hidupnya sehari-hari seperti makanan, minuman, berpakaian, tempat tinggal, dan lain sebagainya. Ketidakpastian ekonomi yang disebabkan oleh pandemi Covid-19 beberapa bulan ini ternyata juga ikut mengakibatkan turun/ hilangnya pendapatan rumah tangga (Sina, 2020). Bahkan Pandemi Covid-19 juga membuat banyak masyarakat yang profesinya rata-rata sebagai pedagang kebingungan karena tidak ada pemasukan dalam kehidupannya sehari-hari akibat dibatasinya pergerakan masyarakat. Akibatnya, banyak masyarakat yang kesulitan mencari uang untuk memenuhi kehidupannya sehari-hari.

Tidak hanya itu saja, sector ekonomi rumah tangga pun mengalami dampak dari terjadinya wabah COVID-19. Menteri Keuangan juga menyatakan bahwa wabah corona akan memperlambat laju pertumbuhan ekonomi Indonesia. Ia mengatakan, wabah corona akan berdampak besar pada laju konsumsi rumah tangga dalam jangka pendek. Turunnya konsumsi membuat pertumbuhan produk domestik bruto atau PDB Indonesia bakal merosot menjadi 2,3\% hingga -0,4\%. Angka ini jauh di bawah asumsi Anggaran Pendapatan dan Belanja Negara (APBN) 2020 yang mencapai 5,3\%. Pemerintah memperkirakan pertumbuhan ekonomi akan turun ke 2,3\% bahkan dalam skenario yang lebih buruk bisa mencapai - 0,4\%. Sektor rumah tangga akan mengalami penurunan cukup besar dari sisi konsumsi karena tidak lagi melakukan aktivitas sehingga konsumsi akan menurun cukup tajam dari 3,22\% hingga 1,60\% (Warta Ekonomi, 2020). 
Dengan demikian, tidak dapat dibantah lagi jika pandemi Covid 19 tentu saja memberikan dampak pada semua sektor kehidupan masyarakat, khususnya pada sektor ekonomi. Sebagai bagian terkecil dari masyarakat, yakni keluarga, keluarga pun ikut terkena dampaknya. Terutama perihal keuangan keluarga. Menurut beberapa ibu rumah tangga yang telah saya berikan survei dan wawancara terkait dampak Covid-19 terhadap keuangan keluarga, tidak sedikit yang mengeluh, manajamen keuangan rumah tangga menjadi terganggu cash - flow nya. Kondisi perekonomian yang mulai sulit seperti ini memaksa ibu - ibu rumah tangga untuk berhati - hati dan lebih cermat dalam mengatur keuangan keluarga. Jangan sampai pandemi ini membuat keuangan keluarga menjadi tidak sehat. Dengan demikian, penelitian ini bertujuan untuk membantu para ibu rumah tangga untuk dapat mengatur keuangan keluarga pada masa pandemi Covid-19 dan membantu para ibu rumah tangga untuk bisa mengelola keuangan keluarga yang lebih baik pada masa pandemi Covid - 19 .

\section{B. PELAKSANAAN DAN METODE}

Pelaksanaan kegiatan pengabdian pada masyarakat dilakukan dalam bentuk penyuluhan dengan khalayak sasaran yang dipilih adalah Ibu - Ibu Pengurus dan Ketua Organisasi HWK (Himpunan Wanita Karya) Medan, Provinsi Sumatera Utara. Tempat yang dipilih adalah Aula Kantor Golkar, Jl. Wahid Hasyim No.12, kota Medan, yang dilakukan secara daring.

\section{Persiapan Kegiatan Pengabdian pada Masyarakat}

Sebelum kegiatan dilaksanakan maka dilakukan persiapan-persiapan sebagai berikut: 
1. Melakukan studi pustaka dari berbagai sumber literatur tentang bagaimana cara mengatur dan mengelola keuangan keluarga dengan baik selama masa pandemi Covid-19 seperti sekarang ini, seperti : mencari beberapa jurnal yang terkait denga apa itu Covid-19, bagaimana cara penyebarannya, dampaknya terhadap perekonomian nasional, sampai dampaknya terhadap ekonomi keuangan keluarga.

2. Melakukan persiapan bahan untuk pembuatan poster terkait sosialisasi dalam bentuk penyuluhan mengatasi keuangan keluarga pada masa pandemi Covid-19 yang menarik dan interaktif.

3. Menentukan waktu pelaksanaan dan lamanya kegiatan pengabdian bersama-sama tim pelaksana.

4. Menentukan dan mempersiapkan materi yang akan disampaikan dalam kegaitan pengabdian masyarakat.

\section{Pelaksanaan kegiatan pengabdian dan Metode}

Pelaksanaan kegiatan pengabdian pada masyarakat berlangsung pada hari Selasa, 24 November 2020 dari pukul 10.30 s /d 12.00 WIB dengan dihadiri 13 peserta dari Ibu - Ibu Pengurus dan Ketua Organisasi HWK (Himpunan Wanita Karya) Medan, Provinsi Sumatera Utara. Kegiatan dilakukan berupa penyampaian materi yang dilakukan secara daring dari Kantor Golkar, Jl. Wahid Hasyim No.12, kota Medan. Metode yang digunakakan dalam kegiatan penyuluhan ini adalah dengan melakukan Manajamen Keuangan Keluarga. Melalui manajemen keuangan keluarga, dipelajari bagaimana cara mengambil keputusan berdasarkan skala prioritas sesuai kondisi keuangan masing - masing keluarga. Implementasi yang dapat diambil dari kegiatan manajemen keuangan keluarga tersebut yakni : melakukan evaluasi sumber penghasilan, menghitung ulang kondisi anggaran keluarga guna mengantisipasi kenaikan biaya-biaya rumah tangga, menggunakan 
sistem pos alokasi anggaran yang lebih sederhana, mengutamakan menyisihkan penghasilan untuk dana darurat, melakukan aktivitasaktivitas produktif yang minim biaya, menangkap peluang dari lingkungan sekitar untuk berjualan di depan atau teras rumah, memanfaatkan jaringan pertemanan untuk menangkap peluang dari sekitar, kemudian juga bisa memanfaatkan jaringan teman sebagai peluang usaha. Semakin banyak kenalan yang dimiliki, semakin luas juga peluang usaha yang bisa didapatkan, dan yang terakhir usaha yang dapat dilakukan adalah bisa dengan mengantisipasi kondisi darurat melalui perlindungan keuangan dengan asuransi- asuransi.

\section{HASIL DAN PEMBAHASAN}

\section{Dampak Covid - 19 Bagi Keluarga}

Penyebaran Covid-19 yang begitu cepat dan masif yang terjadi beberapa bulan ini juga telah menggerus sendi-sendi perekonomian nasional. Aktifitas usaha turun signifikan, perputaran uang menyusut. Ekonomi keluarga pun tak luput dari dampak pandemi ini tentunya (Abdul dkk., 2020). Perekonomian rumah tangga menjadi penting untuk dibahas karena merupakan salah satu komponen yang sangat penting dalam struktur perekonomian nasional. Pengalaman dari beberapa krisis keuangan yang pernah terjadi sebelumnya menunjukkan bahwa kerentanan keuangan sektor rumah tangga sangat mempengaruhi tingkat keparahan krisis keuangan di suatu negara. Dengan demikian, tidak dapat dibantah lagi jika pandemi Covid - 19 tentu saja memberikan dampak pada semua sektor kehidupan masyarakat. Sebagai bagian terkecil dari masyarakat, yakni keluarga, keluarga pun ikut terkena dampaknya (Aidha dkk., 2020). 
Menurut beberapa ibu rumah tangga yang telah saya berikan survei dan wawancara terkait dampak Covid-19 terhadap keuangan keluarga, tidak sedikit yang mengeluh, manajamen keuangan rumah tangga menjadi terganggu cash - flow nya. Pada sektor konsumsi rumah tangga misalnya, terjadi ancaman kehilangan pendapatan masyarakat karena tidak dapat bekerja untuk memenuhi kebutuhan hidup terutama rumah tangga miskin. Belum lagi, banyak juga masyarakat miskin dan menengah ke bawah yang sangat terpengaruh dengan adanya penerapan PSBB (Pembatasan Sosial Berskala Besar) atau penerapan lockdown oleh pemerintah. Pemasukan menjadi sangat rentan karena ketika mereka tidak bekerja, maka pendapatan mereka juga otomatis tidak ada. Dampaknya muncul persoalan baru dalam keuangan rumah tangga tentunya (Anggita dkk., 2020).

Dengan demikian, diperlukan langkah - langkah yang tepat dan cermat agar pengelolaan keuangan kelurga menjadi tepat sasaran. Salah satu upaya yang dapat dilakukan adalah dengan melakukan Manajamen Keuangan Keluarga. Melalui manajemen keuangan keluarga, kita akan belajar bagaimana cara mengambil keputusan berdasarkan skala prioritas sesuai kondisi keuangan masing - masing keluarga. Management Keuangan Keluarga adalah "Seni pengelolaan keuangan yang dilakukan oleh individu atau keluarga melalui orang lain untuk mencapai tujuan yang effesien, efektif dan bermanfaat, sehingga keluarga tersebut tumbuh menjadi keluarga yang sejahtera dan keluarga sakinah" (Badrunsyah dan Cahyono, 2019).

Dalam mengelola manajemen keluarga, yang bertindak sebagai manajer biasanya adalah ibu rumah tangga. Agar dapat mengelola keuangan keluarga secara profesional, keluarga perlu mengetahui beberapa konsep utama tentang manajemen keuangan keluarga yang 
tepat. Ada dua konsep utama tentang manajemen keuangan keluarga yang wajib diketahui oleh keluarga yaitu tentang Neraca dan Rugi/Laba serta Manajemen Cash flow/Arus Kas. Cash flow atau arus kas adalah aliran uang yang mengalir mulai dari kita mendapatkan uang tersebut, menyimpannya, mengembangkannya, dan mengeluarkannya dengan secara teratur, bijak dan disiplin (Ramli dan Apriyanto, 2020). Lebih lanjut dengan merujuk pada e-booklet yang dikeluarkan oleh BKKBN pada tahun 2020 yang lalu, permasalahan utama sebuah keluarga yang selalu ada biasanya seputar keuangan. Hal yang menjadi permasalahan tersebut bisa terjadi karena beberapa faktor, seperti : kekurangan uang, kelebihan uang, atau karena bingung bagaimana mengatur uang bagi orang yang penghasilannya pas-pasan, sedangkan kebutuhan selalu melebihi pemasukan. Adanya pandemi Covid - 19 yang sudah terjadi dalam kurun waktu beberapa bulan ini, ternyata juga ikut menambah permasalahan yang muncul dalam keuangan keluarga. Sehingga, dampak Covid - 19 bagi keluarga dapat dirangkum menjadi tiga hal utama berikut :

1. Krisis moneter global

2. Menurunnya penghasilan keluarga

3. Pengeluaran tambahan untuk biaya kesehatan

Usaha - Usaha yang Dilakukan dalam Mengelola Keuangan Keluarga Kala Pandemi Covid - 19 :

Kebijakan \#DiRumahAja untuk menekan laju kasus baru akibat Covid19 pada kurun waktu yang cukup lama dapat mengakibatkan keluarga terutama yang bergantung dengan upah harian mengalami penurunan penghasilan. Bekerja pun telah dilakukan di dalam rumah demi mengurangi segala kegiatan atau aktivitas di luar ruangan. Bukan tak mungkin bahwa dengan adanya wabah Covid-19 membuat pendapatan 
seseorang menjadi tidak menentu. Saat ini hampir semua lini pekerjaan atau usaha akan terdampak dari kemungkinan penurunan ekonomi akibat Covid-19. Berikut panduan mengelola uang di masa krisis, yang mana ada beberapa hal yang bisa dilakukan untuk menjaga keuangan keluarga tetap teratur dan menjadi lebih baik pada masa pandemi seperti ini, yaitu (BKKBN, 2020) :

\section{Periksa Anggaran Keuangan (Sumber Penghasilan)}

Evaluasi sumber penghasilan. Hal ini dilakukan dengan cara memeriksa pendapatan yang diterima selama pandemi. Apabila pekerjaan kepala keluarga tidak terdampak secara langsung tetap upayakan untuk melakukan penghematan agar biaya hidup rutin tidak semakin bertambah. Sebaliknya, apabila sumber penghasilan terdampak, penyesuaian anggaran keluarga wajib dilaksanakan.

Evaluasi lanjutan dilakukan dengan cara memeriksa apakah masih sama dengan sebelum pandemi atau malah berkurang? Setelah itu, periksa pengeluaran selama ini, catat dengan terperinci hingga pengeluaran yang terkecil. Barangkali di antara kita ada yang terkejut dengan betapa banyaknya pengeluaran kecil yang selama ini tidak diperhitungkan. Misalnya saja pengeluaran bensin untuk hiburan (seperti rekreasi keluarga ke pantai, ke danau, dan tempat lain) biaya parkir, jajan anak-anak, ataupun biaya makan di luar.

\section{Kelola Prioritas Kebutuhan}

Untuk langkah kedua ini, tetapkan pedoman dengan jelas. Menghitung ulang kondisi anggaran keluarga guna mengantisipasi kenaikan biaya-biaya rumah tangga. Harus dapat dengan jelas membedakan antara pengeluaran yang dilakukan atas dasar keinginan atau kebutuhan. Sebaiknya melakukan prioritas pada kebutuhan 
pokok terlebih dahulu. Penuhi kebutuhan pokok keluarga terlebih dahulu seperti : memenuhi kebutuhan makanan keluarga, biaya listrik, biaya air PAM, membayar SPP anak dan biaya rutin bulanan lainnya untuk di rumah. Dengan melakukan prioritas kebutuhan dan berpegang teguh pada kebutuhan bukan keinginan, kita akan bisa lebih berhemat dan tabungan pun tidak akan mudah habis. Mengingat pendapatan keluarga selama masa pandemi mengalami pengurangan atau bahkan ada yang tidak mendapatkan penghasilan, maka sebaiknya jangan memulai cicilan atau memulai hutang baru.

Selain itu tunda juga untuk berinvestasi dengan modal besar seperti membeli properti atau saham. Tunda segala bentuk pengeluaran yang dilakukan atas dasar keinginan saja, misal membeli barang - barang yang tidak terlalu penting baik secara online melalui e-commerce yang tersedia seperti, Lazada, Shopee, Tokopedia, dan lainnya. Ataupun sengaja membeli barang - barang secara offline, yakni dengan mendatangi langsung ke toko untuk berbelanja kebutuhan rumah tangga yang tidak penting.

\section{Bijak Saat Berbelanja}

Cara cermat mengelola keuangan keluarga lainnya yaitu bijak saat hendak berbelanja. Gunakan sistem pos alokasi anggaran yang lebih sederhana. Sebelum pergi ke tempat belanja, catatlah terlebih dahulu dengan terperinci barang-barang yang akan dibeli. Setelah list belanjaan sudah tersedia, kemudian jadwalkan waktu untuk berbelanja. Lebih baik belanja sebulan sekali atau dua minggu sekali. Hal ini dikarenakan, semakin jarang kita pergi ke tempat belanja, akan meminimalisir pengeluaran lain di luar daftar belanjaan. Kemudian, hal penting yang harus dilakukan selama berbelanja adalah dengan melakukan prinsip - prinsip : lakukan perbandingan harga untuk 
masing-masing barang, sehingga dapat dengan mudah mendapatkan dan membeli dengan harga yang murah. Hal lain yang juga bisa dilakukan dengan mengusahakan untuk tetap memanfaatkan promo (gratis ongkos kirim atau promo dari market place). Yakini diri sendiri bahwa kebutuhan terus tersedia di pasaran, sehingga tidak sampai belanja terlalu berlebihan.

\section{Menambah Penghasilan dengan Melihat Peluang Dalam diri dengan Melakukan Aktivitas - Aktivitas Produktif}

Kondisi pandemi yang belum usai memaksa kita untuk bertahan dengan dana yang tersisa. Oleh karena itu agar keuangan keluarga tetap stabil sebaiknya mencari cara untuk bisa menambah penghasilan. Usaha yang dapat dilakukan adalah dengan melakukan aktivitas-aktivitas produktif yang minim biaya dalam rangka merintis pasif income sehingga dapat memberdayakan orang lain dan menjadi tabungan di masa tua.

Tidak perlu takut untuk memulai usaha, kenali potensi diri dan lingkungan untuk bisa menciptakan usaha dalam rangka menambah penghasilan. Temukan potensi yang ada dalam diri dan keahlian apa yang bisa kita gunakan untuk bisa menambah penghasilan. Lihatlah dalam diri kita, apa kelebihan yang dimiliki? Adakah hobi yang bisa dijadikan peluang untuk menambah penghasilan? Bagi yang memiliki hobi memasak, bisa menambah penghasilan dengan cara membuka usaha kuliner di depan / teras rumah. Sedangkan yang memiliki hobi menjahit juga bisa memanfaatkan keahliannya untuk menjahit masker. Seperti diketahui, kebutuhan masker di masa pandemi cukup tinggi. Kita bisa memenuhi kebutuhan tersebut dengan menyediakan masker 
buatan kita sendiri. Kemudian bisa menjual masker tersebut kepada orang - orang terdekat terlebih dahulu, seperti keluarga.

\section{Tangkap Peluang dari Lingkungan Sekitar}

Perhatikan dengan seksama keadaan di sekitar kita. Buka mata dan telinga untuk mengetahui peluang di lingkungan kita. Tanyakan pada diri sendiri, apa yang bisa dilakukan untuk lingkungan kita? Apa produk utama yang ada di daerah kita? Apa masalah yang ada di masyarakat sekitar? Catatlah semua potensi yang bisa jadi peluang untuk menambah penghasilan. Kita bisa memanfaatkan produk utama yang ada untuk dijadikan sumber pendapatan. Misalnya memanfaatkan tahu susu menjadi keripik tahu, mengolah roper menjadi keripik atau membuat keripik dari buah nanas, membuat bakso bakar yang enak, yang mana dalam hal ini karena siswa sekolah sedang dalam masa libur semua, maka kita bisa memanfaatkan teras atau depan rumah kita sebagai lokasi jualan.

Selain memanfaatkan produk utama yang ada di sekitar tempat tinggal, kita juga bisa mengolah limbah menjadi sumber penghasilan. Contohnya mengolah limbah kayu menjadi hiasan dinding atau properti foto. Selanjutnya, kita bisa menyimak perbincangan di lingkungan kita dan menggali apa saja yang menjadi kebutuhan masyarakat yang bisa dijadikan peluang usaha.

\section{Manfaatkan Jaringan Pertemanan}

Selain menangkap peluang dari sekitar, usaha yang juga bisa dilakukan yakni dengan memanfaatkan jaringan teman sebagai peluang usaha. Semakin banyak kenalan yang dimiliki, semakin luas juga peluang usaha yang bisa didapatkan. Hal ini bisa dilakukan dengan mencari hal-hal yang tidak bisa dilakukan oleh teman. Misalnya ada teman yang tidak bisa pergi berbelanja keluar rumah di 
masa pandemi ini karena memiliki anak-anak yang masih kecil, maka kita bisa menawarkan jasa sebagai penyedia kebutuhan pokok keluarganya. Kita juga bisa menyewakan perangkat laptop atau komputer yang kita miliki ketika ada teman yang membutuhkannya untuk digunakan selama work from home. Selama kita cermat mencari potensi di dalam diri dan potensi yang tersedia di lingkungan sekitar, kita bisa mendapatkan tambahan penghasilan untuk menyelamatkan keuangan keluarga.

\section{Persiapkan Dana Darurat dan Perlindungan Keuangan}

Utamakan menyisihkan penghasilan untuk dana darurat sebisa mungkin hingga 12 kali pengeluaran rutin bulanan terutama bagi keluarga yang memiliki tanggungan. apabila dimungkinkan, mengantisipasi kondisi darurat melalui perlindungan keuangan dengan asuransi- asuransi.

\section{Hasil Lokakarya dan Pelatihan}

Berdasarkan wawancara, tanya jawab dan pengamatan langsung selama kegiatan berlangsung, kegiatan pengabdian pada masyarakat ini memberikan hasil sebagai berikut :

1. Meningkatnya pengetahuan dan pemahaman Ibu - Ibu Pengurus dan Ketua HWK Medan, Provinsi Sumatera Utara dalam mengatur keuangan keluarga pada masa pandemi Covid-19.

2. Meningkatnya keterampilan Ibu - Ibu Pengurus dan Ketua HWK Medan, Provinsi Sumatera Utara dalam mengelola dan mengembangkan materi yang telah diberikan selama kegiatan penyuluhan terkait bagaimana langkah - langkah yang tepat dalam memanajemen keuangan keluarga. Para peserta menjadi terbuka pikirannya untuk tidak ragu lagi memulai usaha sesuai kemampuan 
mereka masing - masing, seperti banyak dari ibu - ibu tersebut yang ternyata pandai menjahit masker dan belajar untuk mulai mendistribusikan hasil jahitan nya.

Foto - Foto Kegiatan Selama Kegiatan

Gambar 1.

Poster Seminar

SEIMINAR
Pembicara: Siti Fatimah Sihotang S.Si.M.Si
Kantor Golkar Jl. Wahid Hasyim Medan 24 Nov2020

Gambar 2.

Tampilan Cover Slide Materi Penyuluhan

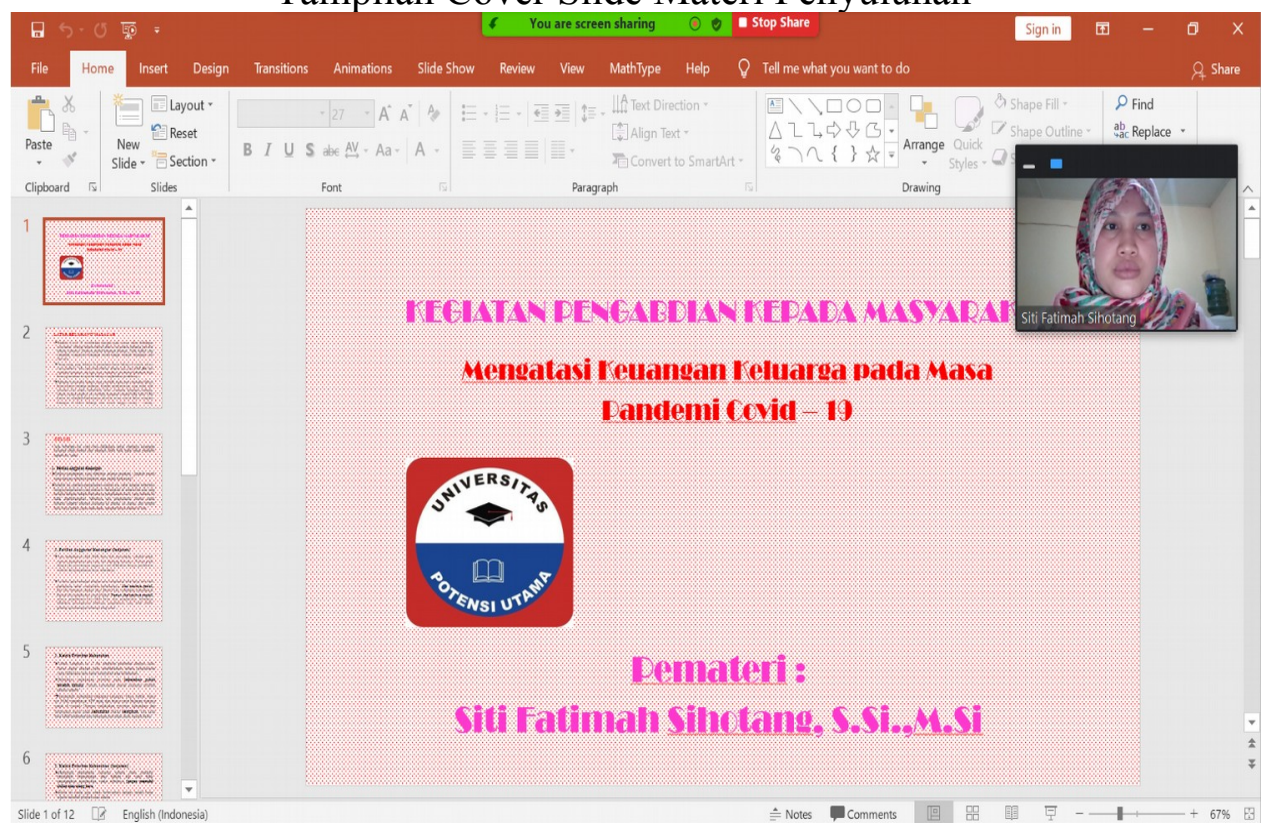

Gambar 3.

Tampilan Kesimpulan Materi Penyuluhan 


\section{KESIMPULAN}

- Diakui atau tidak, mengatur keuangan keluarga dengan cermat di masa pandemi seperti sekarang ini sudah menjadi kebutuhan yang mendesak. Apalagi kini perekonomian sedang tidak menentu. Dan untuk mendapatkan pondasi keuangan yang kuat, kunci utamanya yaitu membuat dan teguh pada anggaran yang kita buat.

- Kemudian, tidak ada salahnya juga jika kita menyiapakan Dana Darurat. Dana Darurat adalah dana yang harus siap sedia jika ada halhal yang tidak diinginkan membutuhkan pemakaian dana tersebut. Seperti apakah kondisi yang membutuhkan dana darurat? Jika ada salah satu anggota mengalami sakit dan harus dirawat di rumah sakit meskipun memiliki asuransi kesehatan dari kantor suami yang akan mengcover biaya perawatan inap di rumah sakit tetapi ternyata tidak semuanya di cover misalkan ada pemeriksaan laboratorium, obat atau alat kesehatan tertentu.

\section{Gambar 4.}

Seluruh Peserta Kegiatan Penyuluhan

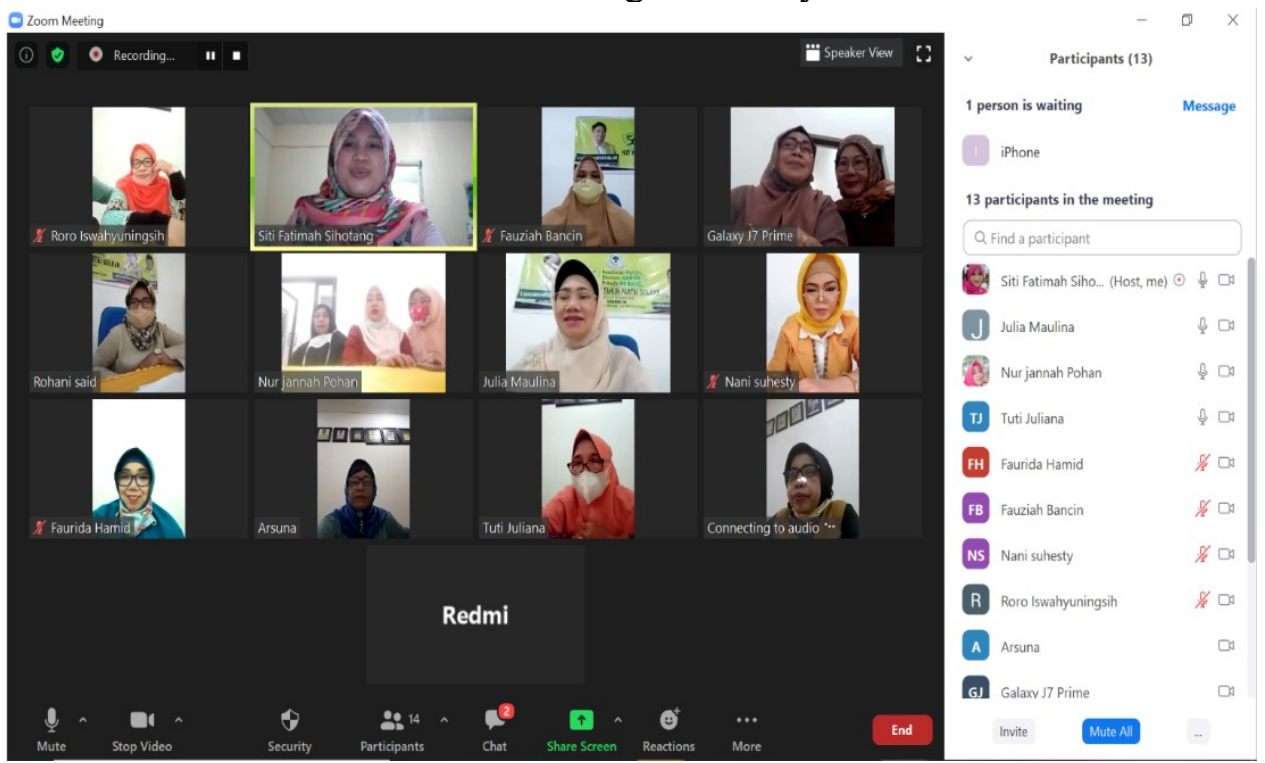




\section{KESIMPULAN}

Berdasarkan analisis hasil kegiatan dapat disimpulkan beberapa hal sebagai berikut:

1. Setelah dilaksanakannya kegiatan penyuluhan, pengetahuan dan pemahaman Ibu - Ibu pengurus dan Ketua HWK Medan meningkat dalam hal mengatur dan mengelola keuangan keluarga pada masa pandemi Covid - 19 .

2. Minat dan kesadaran Ibu - Ibu pengurus dan Ketua HWK meningkat untuk mulai berani memulai usaha, apalagi banyak dari Ibu - Ibu tersebut ternyata mempunyai keahlian untuk menjahit masker, sehingga bisa dimulai dengan memulai usaha untuk menjahit masker dan menjualnya kepada anggota keluarga yang terdekat terlebih dahulu.

3. Sebagai pengelola keuangan keluarga dalam rumah tangga, diharapkan agar Ibu - Ibu pengurus dan Ketua HWK mampu menerapkan dan menjalankan ilmu prinsip manajemen keuangan keluarga yang tepat dengan penuh ketekunan dan kekonsistenan.

\section{Faktor Pendukung dan Faktor Penghambat}

Beberapa faktor yang mendukung terlaksananya kegiatan pengabdian pada masyarakat ini adalah besarnya minat dan antusiasme peserta selama kegiatan, sehingga kegiatan berlangsung dengan lancar dan efektif. Sedangkan faktor penghambatnya adalah keterbatasan waktu lokakarya serta masih kurangnya ketersediaan laptop / komputer dan jaringan internet yang memadai di Aula kantor HWK Provinsi Sumatera Utara untuk beberapa ibu-ibu peserta tersebut sebagai media penyuluhan karena ternyata banyak dari ibu - ibu peserta yang jaringan dari HP nya tidak terlalu bagus dan layar HP nya yang kecil. 


\section{E. UCAPAN TERIMA KASIH}

Dalam kesempatan ini, penulis mengucapkan terima kasih yang sebesar-besarnya kepada:

1. Ketua Lembaga Pengabadian Pada Masyarakat UPU (Universitas Potensi Utama) yang telah memberikan kemudahan dalam pelaksanan pengabdian.

2. Ibu - Ibu Pengurus dan Ketua Organisasi HWK (Himpunan Wanita Karya) Medan, Provinsi Sumatera Utara yang telah turut berpartisifasi aktif dalam pelaksanaan kegiatan pengabdian ini. 


\section{DAFTAR PUSTAKA}

Abdul, A., Rosa Mia, A., Suzette, D., Benno, F., Ilan, N., Patrick, O., Jesson, P., Donghyun, P., \& Reizle, P. (2020). The Economic Impact of the Covid-19. ADB Brief No. 128. https://www.adb.org/ publications/ economic-impactcovid19-developing-asia.

Aidha, N.C., Armintasari, F., Mawesti, D. (2020). Perkumpulan Prakarsa, Prakarsa Policy Brief. Risiko Keterlilitan Utang Rumah Tangga di Tengah Pandemi COVID-19. Versi Bahasa Indonesia ke-23, 4 halaman.

Anggita, W., Julia, Suhaidar, Rudianto, N.A.R. (2020). Peningkatan Pemahanan Literasi Keuangan di Era Pandemi Corona Sebagai Upaya Penguatan Ketahanan Ekonomi Keluarga. Jurnal Pengabdian kepada Masyarakat Universitas Bangka Belitung Vol. 7 No.2, Desember 2020. P-ISSN : 2407-5027, E-ISSN : 26226448.

Badrunsyah dan Cahyono, S. (2019). Penyuluhan Tentang Manajemen Keuangan Keluarga Di RW 06 Kelurahan Cipayung Jakarta Timur, Jurnal Pelayanan dan Pengabdi. Masy.,vol. 3, No. 1, pp. 1-9.

Bedford, J., Enria, D., Giesecke, J., Heymann, DL., Ihekweazu, C., \& Kobinger, G. (2020). COVID-19: Towards Controlling of a Pandemic. The Lancet. Doi: 10.1016/S0140-6736(20)30673-5.

E-Booklet BKKBN Pengelolaan Keluarga pada Era Pandemik Covid-19.

(2020). Direktorat Pemberdayaan Ekonomi Keluarga Badan Kependudukan dan Keluarga Berencana Nasional. 20 Halaman.

Hanoatubun, Silpa. (2020). Dampak Covid-19 Terhadap Perekonomian Indonesia. EduPsyCouns Journal, Journal of Education, 
Psychology and Counseling. Volume 2 nomor 1. ISSN Online : 2716-4446

Hakim, Z., Muttaqin, I., \& Mudarris, M. (2020). Revitalisasi Jembatan Desa Sebagai Akses Aktivitas Perekonomian Desa Bangpindah Kecamatan Galis Bangkalan. Dharma: Jurnal Pengabdian Masyarakat, 1(1), 38-48.

He, F., Deng, Y., \& Li, W. (2020). Coronavirus Disease 2019: What We Know? Journal of Medical Virology. Doi: 10.1002/jmv.25766.

Junaidi, J., Ramdhan, T. W., \& Putera, K. B. (2020). Membangun Ekonomi Pasca Covid 19 di Desa Sadah Tanah Merah Bangkalan Melalui Pelatihan Pembuatan Keripik Kelapa. Dharma: Jurnal Pengabdian Masyarakat, 1(1), 17-27.

Ramli, M., Apriyanto, M. (2020). Manajemen Keuangan untuk Meningkatkan Perekonomian Keluarga di Masa Pandemi COVID19. Jurnal BAPPEDA.

Warta Ekonomi. 2020. Menkeu: Pandemi Corona Pukul Konsumsi Rumah Tangga. https://www.wartaekonomi.co.id/read279104/menkeupandemi-corona-pukulkonsumsi-rumah-tangga 